\title{
Quality Evaluation of River Chanchaga Using Metal Pollution Index and Principal Component Analysis
}

\author{
A. N. Amadi ${ }^{1}$, J. Yisa ${ }^{2}$, I. C. Ogbonnaya ${ }^{3}$, M. A. Dan-Hassan ${ }^{4}$, J. O. Jacob ${ }^{2} \&$ Y. B. Alkali ${ }^{1}$ \\ ${ }^{1}$ Department of Geology, Federal University of Technology, Minna, Nigeria \\ ${ }^{2}$ Department of Chemistry, Federal University of Technology, Minna, Nigeria \\ ${ }^{3}$ Department of Soil Science, Federal University of Technology, Minna, Nigeria \\ ${ }^{4}$ Rural Water Supply and Sanitation Department, FCT Water Board, Garki, Abuja, Nigeria \\ Correspondence: A. N. Amadi, Department of Geology, Federal University of Technology, Minna, Nigeria. Tel: \\ 234-818-821-8076. E-mail: geoama76@gmail.com
}

\author{
Received: February 15, 2012 Accepted: February 27, 2012 Online Published: May 10, 2012 \\ doi:10.5539/jgg.v4n2p13 \\ URL: http://dx.doi.org/10.5539/jgg.v4n2p13
}

\begin{abstract}
In this study, metal pollution index (MPI) and principal component analysis (PCA) techniques were applied to water quality data sets obtained from River Chanchaga, Minna, North-central Nigeria, to obtain the spatial and temporal changes in the river quality. Results show that the indices which changed the quality of the river water consist of natural (weathering and bedrock dissolution) and anthropogenic activities such as mining, agriculture, domestic and industrial wastes within its catchment. The result of the MPI indicates that the river is slightly affected with respect to heavy metal pollution, which can be attributed the gold mineralization and mining along the river course. Five principal factors were generated when the data was subjected to PCA and they correspond to five possible point source of pollution to the river. Factors 1 and 2 are naturally induced while factors 3,4 and 5 are due to anthropogenic interference in the hydrological cycle. Although, the river quality does not pose any serious threat to human health presently, the various anthropogenic activities domiciled at the downstream should discontinue, in order restore the river water quality. The people living close to the river should adopt a good sanitary habit by not dumping waste into the river henceforth. Boiling of the water before consumption is advocated.
\end{abstract}

Keywords: water quality, metal pollution index, principal component analysis, Chanchaga River, Minna, North-central Nigeria

\section{Introduction}

River Water quality monitoring is necessary especially where the water serves as drinking water sources, are threatened by pollution resulting from various human activities along the river course (Ahmad et al., 2010; Amadi, 2011). Heavy metals contamination in river is one of the major quality issues in many fast growing cities, because maintenance of water quality and sanitation infrastructure did not increase along with population and urbanization growth, especially for the developing countries (Sundaray et al., 2006; Karbassi et al., 2007; Akoto et al., 2008; Amadi et al., 2010). Heavy metals contamination is important due to their potential toxicity for the environment and human beings (Gueu et al., 2007; Lee et al., 2007; Adams et al., 2008; Vinodhini \& Narayanan, 2008). Some of the metals such as $\mathrm{Cu}, \mathrm{Fe}, \mathrm{Mn}, \mathrm{Ni}$ and $\mathrm{Zn}$ are essential as micronutrients for the life processes in animals and plants while many other metals such as $\mathrm{Cd}, \mathrm{Cr}, \mathrm{Pb}$ and $\mathrm{Co}$ have no known physiological activities (Kar et al., 2008; Suthar \& Singh, 2008; Aktar et al., 2010). Metals are non-degradable and can accumulate in the human body system, causing damage to nervous system and internal organs (Lee et al., 2007; Lohani et al., 2008). They enter into river water from mining areas through various ways such as mine discharge, run-off, chemical weathering of rocks and soils, wet and dry fallout of atmospheric particulate matter (Macklin et al., 2003; Bird et al., 2003; Kraft et al., 2006; Venugopal et al., 2009) or from industrial areas via discharge of untreated industrial effluent in the river (Singh et al., 2008). Rivers in urban areas have also been associated with water quality problems because of the practice of discharging of untreated domestic and small scale industries into the water bodies which leads to the increase in the level of metals concentration in river water (Rim-Rekeh et al., 2006; Khadse et al., 2008; Juang et al., 2009; Venugopal et al., 2009; Sekabira et al., 2010). However, 
rivers play a major role in assimilation or transporting municipal and industrial wastewater and runoff from agricultural and mining land (Singh et al., 2004).

Furthermore, Rivers are dynamic systems and may change in nature several times during their course because of changes in physical conditions such as slope and bedrock geology. They carry horizontal and continuous one-way flow of a significant load of matter in dissolved and particulate phases from both natural and anthropogenic sources. This matter moves downstream and is subject to intensive chemical and biological transformations. The surface water chemistry of a river at any point reflects several major influences, including the lithology of the catchment, atmospheric inputs, climatic conditions and anthropogenic inputs. Identification and quantification of these influences should form an important part of managing land and water resources within a particular river catchment (Bellos \& Swaidis, 2005).

Rapid urbanization and industrial development during last decade have provoked some serious concerns for the environment. Usually in unaffected environments, the concentration of most of the metals is very low and is mostly derived from the mineralogy and the weathering (Karbassi et al., 2008). Main anthropogenic sources of heavy metal contamination are mining, disposal of untreated and partially treated effluents contain toxic metals, as well as metal chelates from different industries and indiscriminate use of heavy metal-containing fertilizer and pesticides in agricultural fields (Hatje et al., 1998; Amman et al., 2002; Nouri et al., 2006; Nouri et al., 2008). The mine water, runoff from abandoned watersheds and associated industrial discharges are the major source of heavy metal contamination, total dissolved solid (TDS) and low pH of rivers (USEPA, 1997; Mohanty et al., 2001; Cravotta, 2008; Shahtaheri et al., 2008). The present study aimed at assessing the quality status of River Chanchaga with emphasis on heavy metal and bacteriological contaminations.

\section{Materials and Methods}

\subsection{Location, Geology and Hydrogeology of the Area}

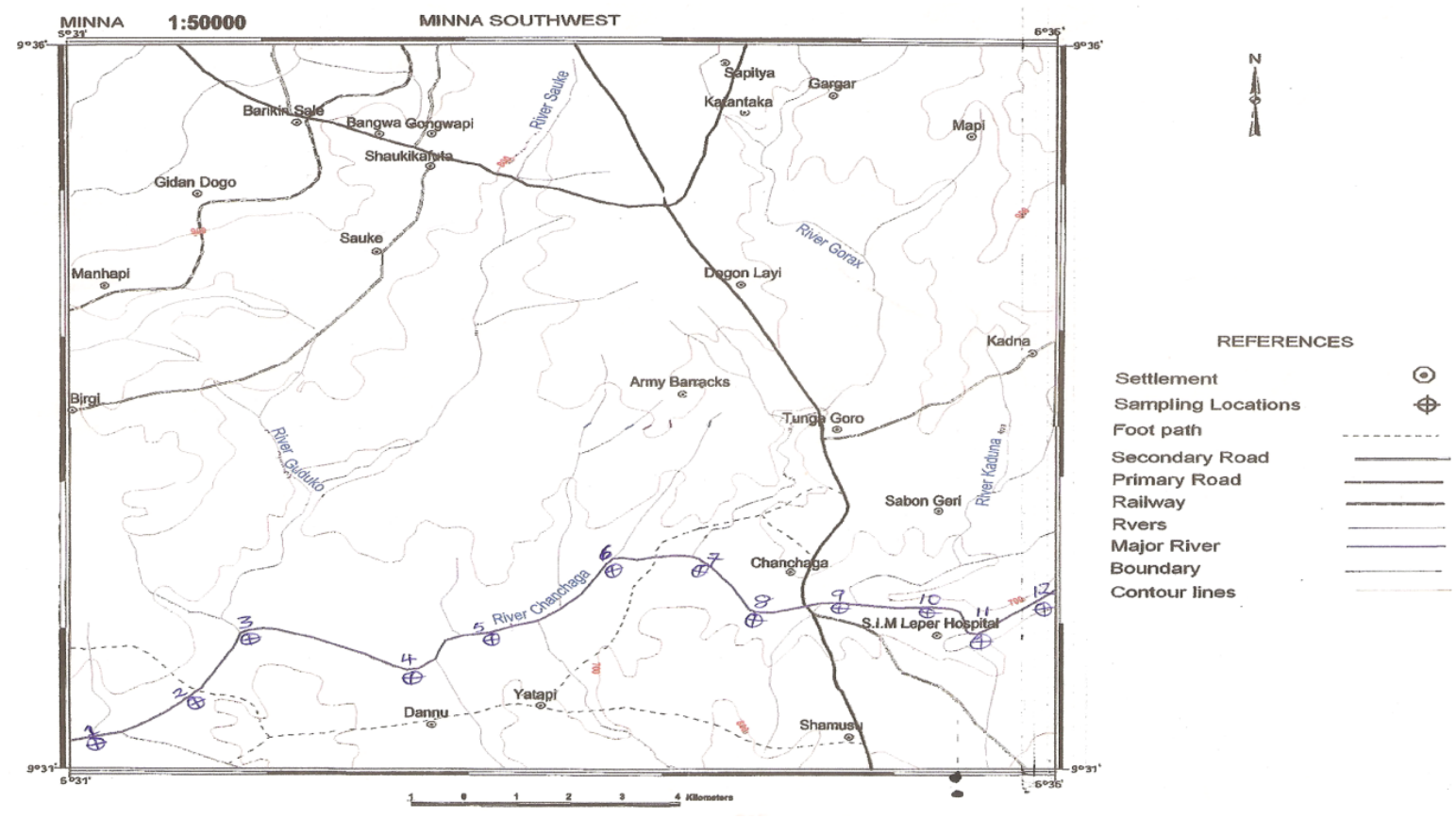

Figure 1. Topo map of Minna showing River Chanchaga (NGSA, 2004)

River Chanchaga is located at the southern part of Minna, Niger State Capital, and lies between latitudes $6^{0} 31^{\mathrm{I}} \mathrm{N}$ to $6^{0} 36^{\mathrm{I}} \mathrm{N}$ and longitudes $9^{0} 31^{\mathrm{I}} \mathrm{E}$ to $9^{0} 36^{\mathrm{I}} \mathrm{E}$ (Figure 1). The study area is predominantly underlain by the pre-Cambrian Basement Complex rocks. The local lithological units in the study area are granite, gneiss and schist. The granite is the most wide spread rock unit and are porphyritic, medium-coarse-grained in texture. The granites mostly occur as intrusive, low-lying outcrops into the gneisses. They are severely jointed and fairly incised by quartz veins. The major structural features in the study area are fractures and lineaments. North of the river, the lineaments trend NE-SW direction while in the south, close to River Chanchaga, lineaments trend 
NW-SE. This implies that the NW-SE flow of River Chanchaga is structurally controlled (Figure 2). Evidence from satellite imagery of the area revealed that the southeastern part of the study area with low fracture density correspond with areas covered by soil and highly weathered thick overburden (Figure 3). The major fractures observed in the area are the signatures of the Pan African Orogeny (600ma), which is the major tectonic event that produced structural deformation of the area (Ajibade \& Wright, 1988).

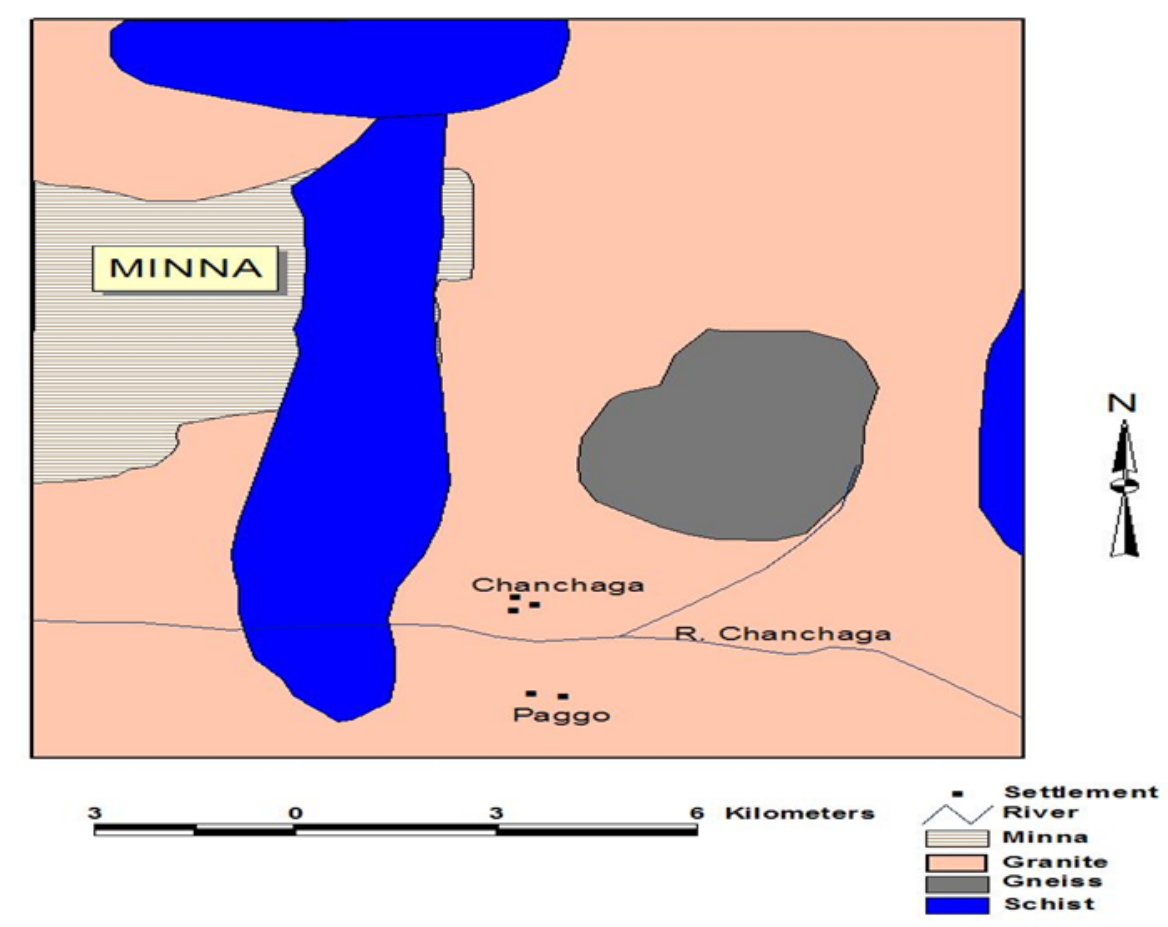

Figure 2. Geological map of parts of Minna (Source: NGSA, 200)

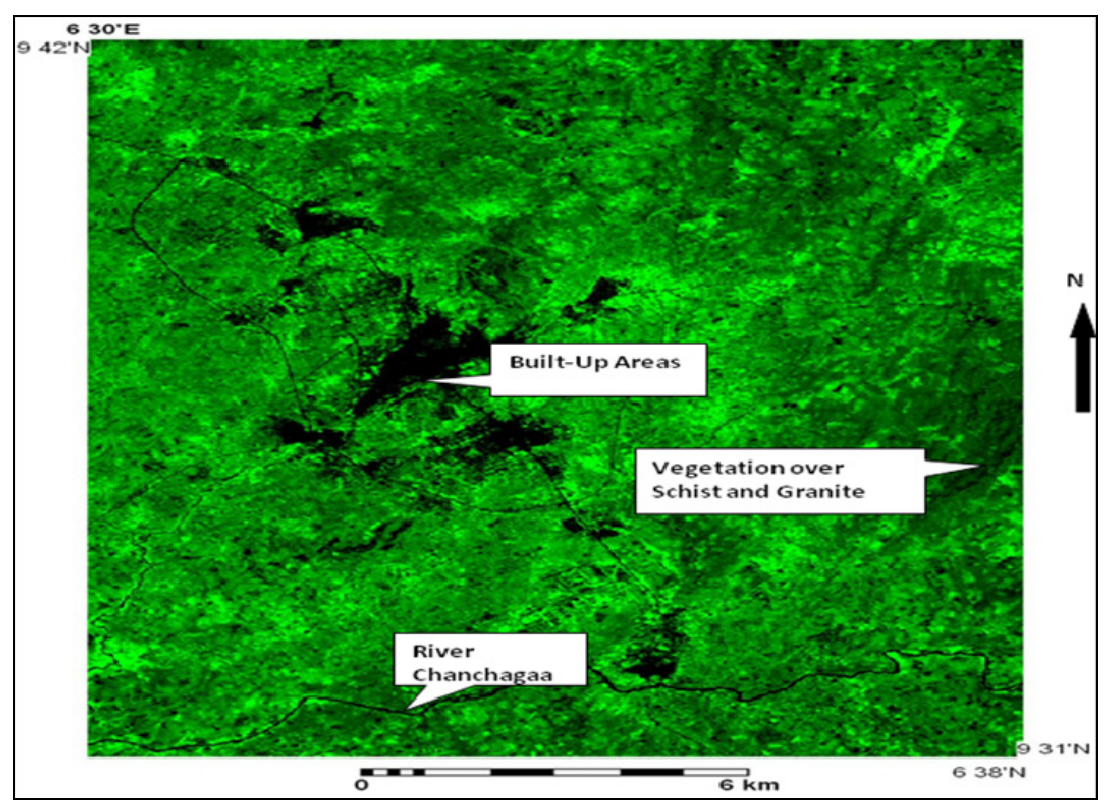

Figure 3. Interpreted band four imagery on stretching (Source: Amadi \& Olasehinde, 2010) 


\subsection{Water Sampling and Laboratory Analysis}

Twelve sampling stations were established along the river course in order to obtain a good knowledge of the overall quality of the river and this was monitored for a period of one year by taking samples from each sampling station once in every month. Water samples were taken from 10 to $15 \mathrm{~cm}$ below the water surface using acid washed plastic container to avoid unpredictable changes in characteristic as per standard procedures (APHA, 1998). Samples for metal analysis were collected separately and acidified at site $(\mathrm{pH}<2)$ with concentrated nitric acid $\left(\mathrm{HNO}_{3}\right)$. All the samples collected in tight capped high quality polyethylene bottles were immediately transported the laboratory under low temperature conditions in ice-boxes for relevant chemical and microbial analysis. Prior to chemical and microbial analysis physical parameters such as temperature, $\mathrm{pH}$, and conductivity were determined insitu using mercury thermometer, $\mathrm{pH}$ meter (model 744, Metrohm, Switzerland) and conductivity meter (model 162A, ThermOrion, USA). Major anions $\left(\mathrm{Cl}^{-}, \mathrm{SO}_{4}{ }^{2-}, \mathrm{NO}_{3}{ }^{-}, \mathrm{HCO}_{3}{ }^{-}\right.$and $\mathrm{CO}_{3}{ }^{-}$) were analyzed using modular Ion Chromatograph (Metrohm, Switzerland) while $\mathrm{Na}^{+}$and $\mathrm{K}^{+}$were analyzed by Flame Photometer (model CL-360, Elico, India). The analysis of $\mathrm{Ca}^{2+}, \mathrm{Mg}^{2+}, \mathrm{Pb}, \mathrm{Mn}, \mathrm{Fe}, \mathrm{Cu}, \mathrm{Zn}$ and As was done using AAS (model Analyst 300, Perkins-Elmer, USA) while microbial analyses of E.coli and total coliform were carried out using presumptive count.

\subsection{Metal Pollution Index}

Metal Pollution index (MPI) is a method of rating that shows the composite influence of individual parameters on the overall quality of water (Tamasi \& Cini, 2004). The rating is a value between zero and one, reflecting the relative importance individual quality considerations. The higher the concentration of a metal compared to its maximum allowable concentration, the worse the quality of the water (Amadi, 2011). It is also a combined physio-chemical and microbial index which makes it possible to compare the water quality of various water bodies (Filatov et al., 2005). It has wide application and it is used as the indicator of the quality of sea (Filatov. et al., 2005) and river water (Lylko et al., 2001; Amadi, 2012), as well as drinking water (Nikoladis et al., 2008; Amadi et al., 2010). The MPI represents the sum of the ratio between the analyzed parameters and their corresponding national standard values (Tamasi and Cini, 2004) as shown below:

$$
M P I=\sum_{i=1}^{n}\left[\frac{C i}{(M A C) i}\right]
$$

where: $\mathrm{Ci}$ : mean concentration

MAC: maximum allowable concentration

Water quality and its suitability for drinking purpose can be examined by determining its metal pollution index (Mohan et al., 1996; Prasad \& Kumari, 2008).

\subsection{Principal Component Analysis (PCA)}

The principal component analysis (PCA) technique extracts the eigenvalues and eigenvectors from the covariance matrix of original variables, thus, reducing the dimensionality of the data set. The principal components (PCs) are the uncorrelated (orthogonal) variables, obtained by multiplying the original correlated variables with the eigenvector (loadings). The eigenvalues of the PCs are the measure of their associated variance, the participation of the original variables in the PCs is given by the loadings, and the individual transformed observations are called scores (Prasad \& Mondal, 2008; Amadi, 2011). PCA was performed on normalized (z-scale transformation) on 20 variables after sorting out the highly correlated variable from the data sets. The Bartlett's sphericity test was applied to the correlation matrix of variables for assessing the adequacy of PCA in water quality studies (Lambarkis et al., 2004). The PCs with eigenvalues $>1$ were retained and are used to assess the compositional, temporal and spatial variations in the river quality due to anthropogenic activities domiciled along the river course (Singh et al., 2008; Sundarary, 2009; Amadi, 2012).

\section{Results}

The results the laboratory analysis of the river water data is summarized in Table 1 while water quality classification according to metal pollution index are shown in Table 2. The hydrochemical data were subjected to principal component analysis and the result illustrated in Table 3. 
Table 1. Statistical summary of the river water data and the maximum allowable concentration by the Nigerian Standard for Drinking Water Quality (NSDWQ, 2007)

\begin{tabular}{lllll}
\hline Parameters $(\mathrm{mg} / \mathrm{l})$ & Minimum & Maximum & Mean $(\mathrm{Ci})$ & NSDWQ, 2007 \\
\hline Temperature $\left({ }^{\circ} \mathrm{C}\right)$ & 27.00 & 33.00 & 30.00 & Ambient \\
pH & 6.60 & 9.50 & 7.80 & $6.50-8.50$ \\
Conductivity $(\mu \mathrm{s} / \mathrm{cm})$ & 115.00 & 1570.00 & 553.00 & 1000.00 \\
Chloride & 0.75 & 220.00 & 58.12 & 250.00 \\
Sulphate & 0.20 & 118.00 & 24.82 & 100.00 \\
Nitrate & 0.30 & 58.00 & 12.86 & 50.00 \\
Bicarbonate & 0.05 & 120.00 & 38.66 & 100.00 \\
Carbonate & 0.00 & 67.00 & 9.04 & 100.00 \\
Calcium & 3.32 & 225.00 & 85.65 & 200.00 \\
Magnesium & 4.31 & 212.00 & 78.32 & 200.00 \\
Sodium & 0.80 & 106.00 & 57.30 & 200.00 \\
Potassium & 0.10 & 85.00 & 32.60 & 150.00 \\
Lead & 0.00 & 0.05 & 0.02 & 0.01 \\
Manganese & 0.00 & 0.27 & 0.13 & 0.20 \\
Iron & 0.00 & 2.10 & 0.50 & 0.30 \\
Copper & 0.00 & 2.03 & 1.04 & 1.00 \\
Zinc & 0.01 & 3.45 & 2.60 & 3.00 \\
Arsenic & 0.00 & 0.02 & 0.01 & 0.01 \\
E.coli $(\mathrm{cfu} / 100 \mathrm{ml})$ & 0.00 & 6.00 & 2.00 & 0.00 \\
Total coliform $(\mathrm{cfu} / \mathrm{ml})$ & 0.00 & 35.00 & 13.00 & 10.00 \\
\hline
\end{tabular}

Table 2. Water Quality Classification using MPI (Lyulko et al., 2001; Caerio et al., 2005)

\begin{tabular}{lll}
\hline Class & Characteristics & MPI \\
\hline I & Very pure & $<0.3$ \\
II & Pure & $0.3-1.0$ \\
III & Slightly affected & $1.0-2.0$ \\
IV & Moderately affected & $2.0-4.0$ \\
V & Strongly affected & $4.0-6.0$ \\
VI & Seriously affected & $>6.0$ \\
\hline
\end{tabular}

Table 3. Principal component analysis of the river water data

\begin{tabular}{llllll}
\hline Parameters $(\mathrm{mg} / \mathrm{l})$ & PC-1 & PC-2 & PC-3 & PC-4 & PC-5 \\
\hline Temperature $\left({ }^{\circ} \mathrm{C}\right)$ & 0.012 & 0.268 & $\mathbf{0 . 7 8 5}$ & 0.206 & -0.195 \\
$\mathrm{pH}$ & 0.170 & $\mathbf{0 . 6 0 9}$ & 0.158 & -0.186 & 0.235 \\
Conductivity $(\mu \mathrm{s} / \mathrm{cm})$ & $\mathbf{0 . 8 1 2}$ & 0.375 & 0.174 & 0.103 & 0.202 \\
Chloride & $\mathbf{0 . 7 2 8}$ & 0.304 & 0.158 & 0.250 & 0.158 \\
Sulphate & 0.390 & $\mathbf{0 . 6 2 7}$ & 0.345 & 0.109 & 0.050 \\
Nitrate & 0.232 & 0.230 & $\mathbf{0 . 6 1 7}$ & 0.220 & 0.105 \\
Bicarbonate & 0.343 & $\mathbf{0 . 5 9 0}$ & 0.384 & 0.037 & -0.246 \\
Carbonate & 0.482 & $\mathbf{0 . 6 6 1}$ & -0.195 & 0.134 & 0.328 \\
Calcium & $\mathbf{0 . 8 3 1}$ & 0.402 & 0.109 & 0.240 & 0.270 \\
Magnesium & $\mathbf{0 . 6 1 5}$ & 0.013 & 0.374 & 0.202 & 0.216 \\
Sodium & $\mathbf{0 . 7 4 5}$ & 0.193 & -0.281 & 0.152 & 0.317 \\
Potassium & $\mathbf{0 . 6 9 3}$ & 0.145 & 0.365 & 0.138 & 0.202 \\
Lead & 0.234 & -0.013 & 0.417 & 0.105 & $\mathbf{0 . 8 4 5}$ \\
Manganese & -0.310 & 0.250 & 0.309 & $\mathbf{0 . 6 1 0}$ & 0.128 \\
Iron & 0.112 & $\mathbf{0 . 5 2 3}$ & 0.234 & 0.103 & 0.240 \\
Copper & 0.021 & 0.163 & 0.270 & $\mathbf{0 . 5 4 9}$ & 0.101 \\
Zinc & 0.239 & 0.321 & 0.378 & $\mathbf{0 . 6 5 2}$ & 0.321 \\
Arsenic & -0.090 & 0.123 & 0.205 & 0.145 & $\mathbf{0 . 6 5 4}$ \\
E.coli $(\mathrm{cfu} / 100 \mathrm{ml})$ & 0.174 & 0.231 & $\mathbf{0 . 5 6 2}$ & -0.298 & 0.245 \\
Total coliform $(\mathrm{cfu} / \mathrm{ml})$ & 0.312 & -0.200 & $\mathbf{0 . 6 8 4}$ & 0.311 & 0.320 \\
Eigenvalue & 4.792 & 3.458 & 2.215 & 1.840 & 1.132 \\
\% of Variance & 28.567 & 22.714 & 15.361 & 11.852 & 8.684 \\
Cumulative \% & 28.567 & 51.281 & 66.642 & 78.494 & 87.178 \\
\hline
\end{tabular}




\section{Discussions}

The temperature values ranged between $27.00{ }^{\circ} \mathrm{C}$ to $33.00{ }^{\circ} \mathrm{C}$ and an average temperature $30.00{ }^{\circ} \mathrm{C}$ while the pH varied from 6.60-9.50 with a mean value of 7.80. The conductivity values ranged between $115.00 \mathrm{mg} / \mathrm{l}$ to $1570.00 \mu \mathrm{s} / \mathrm{cm}$ with a mean value of $553.00 \mu \mathrm{s} / \mathrm{cm}$ (Table 1). The natural and anthropogenic inference in the river course may be responsible for the the slightly alkalinity and conductivity of the river water. All the major anions (chloride, sulphate, bicarbonate and carbonate) have the concentrations below the maximum permissible limit postulated by the Nigerian Standard for Drinking Water Quality (NSDWQ, 2007) for a safe drinking water except nitrate, whose concentration in some sampling points is slightly higher than the $50.00 \mathrm{mg} / \mathrm{l}$ maximum acceptable values (NSDWQ, 2007). The application of fertilizer by farmers along the river banks and urban runoff might be contributing factors.

The concentration of sodium ranged between $0.80 \mathrm{mg} / \mathrm{l}$ to $106.00 \mathrm{mg} / \mathrm{l}$ with an average concentration of 53.30 $\mathrm{mg} / \mathrm{l}$ while potassium concentration varied from $0.10-85.00 \mathrm{mg} / \mathrm{l}$ with a mean concentration of $32.60 \mathrm{mg} / \mathrm{l}$. These values fall below the allowable limits of $200.00 \mathrm{mg} / 1$ and $150.00 \mathrm{mg} / 1$ for sodium and potassium respectively (NSDWQ, 2007). Calcium concentration ranged between $2.32 \mathrm{mg} / \mathrm{l}$ to $225.00 \mathrm{mg} / \mathrm{l}$ with an average value of $85.65 \mathrm{mg} / \mathrm{l}$ while the concentration of magnesium varied from $4.31-212.00 \mathrm{mg} / 1$ with a mean value of $78.32 \mathrm{mg} / 1$ (Table 1). The slightly high concentration of Calcium and magnesium (>200.00 mg/l) in some locations can be attributed to bedrock dissolution and chemical weathering of ferromagnesian minerals. The concentration of lead varied from $0.00-0.05 \mathrm{mg} / \mathrm{l}$ and a mean value of $0.02 \mathrm{mg} / \mathrm{l}$ while the concentration of manganese ranged between $0.00-0.27 \mathrm{mg} / 1$ with an average concentration of $0.13 \mathrm{mg} / \mathrm{l}$ (Table 1). The concentration of iron ranged between $0.00 \mathrm{mg} / \mathrm{l}$ to $2.10 \mathrm{mg} / \mathrm{l}$ and a mean of $0.50 \mathrm{mg} / \mathrm{l}$ while that of copper varied from $0.00-2.03 \mathrm{mg} / \mathrm{l}$ with average of $1.04 \mathrm{mg} / \mathrm{l}$. Zinc concentration ranged between $0.01 \mathrm{mg} / \mathrm{l}$ to $3.45 \mathrm{mg} / \mathrm{l}$ with a mean value of $2.60 \mathrm{mg} / \mathrm{l}$ while arsenic concentration varied from $0.00-0.02 \mathrm{mg} / \mathrm{l}$ with an average value of $0.01 \mathrm{mg} / \mathrm{l}$.

The concentration of these heavy metal ( $\mathrm{Pb}, \mathrm{Mn}, \mathrm{Fe}, \mathrm{Cu}, \mathrm{Zn}$ and $\mathrm{As})$ were introduced into the river water system probably through exploration and exploitation of gold on the downstream of the river. These metals occur in association with gold and are usually discarded due to economic reasons and because of their biodegradable nature, they accumulate over the years in soils and are carried by runoff into the river system. Also, the discharge of untreated urban waste in the vicinity of the river may enrich the river with some of these metals. The mean concentration of E.coli and total coliform are $2.00 \mathrm{cfu} / 100 \mathrm{mgl}$ and $13.00 \mathrm{cfu} / \mathrm{ml}$ respectively (Table 1 ). These may be due to dumping of human and animal faeces/wastes by people into or near the rivers.

The five principal components were identified to be responsible for the deterioration of the river water and accounts for $87.18 \%$ of the overall total variance. The first principal component accounts for $28.57 \%$ of the total variance and is characterized by high loading for conductivity, chloride, calcium, magnesium, sodium and potassium. The presence of these elements shows some degree of mineralization of river water due to high rates of evaporation and dissolution processes. The second major component accounts for $22.71 \%$ and comprises of $\mathrm{pH}$, sulphate, bicarbonate, carbonate and iron. Chemical weathering of rock-forming minerals may be a source of their enrichment in the surface water. From the geological mapping carried out, the dominant rock unit in the area is granite, and the major cations and anions in the river water are likely from the lithology via weathering/dissolution processes and it is a function of $\mathrm{pH}$. Their presence increases the conductivity of the water (Khadse et al., 2008; Kar et al., 2008).

The third principal component consists of temperature, nitrate, E.coli and total coliform which accounts for $15.36 \%$ of the total variance. Agricultural activities taking place along the river course may be responsible for the high nitrate concentration at some sampling points. The presence of E.coli and total coliform in water signifies faecal contamination due to dumping of human and animal faeces into and or near the river and the growth of these microbes in water is a function of the water temperature. The fourth principal component has a moderate loading of $11.85 \%$ of the total variance and contains Manganese, Copper and Zinc while the fifth principal component represents $8.68 \%$ of the total variance with lead and Arsenic as the contributors. The gold mining and other anthropogenic activities at the downstream of the river may be responsible for the presence of these heavy metals in the surface water. Pyrite $(\mathrm{FeS} 2)$, galena $(\mathrm{PbS})$ and other accessory mineral which occurs simultaneously with gold are discarded and are transported in form of runoff to the river system thereby contaminating it.

\section{Conclusion}

The quality of River Chanchaga has been evaluated using metal pollution index and principal component analysis. The result of the MPI suggests that the river is slightly affected with respect to heavy metal pollution and it is attributed the gold mineralization and mining near the river course. Five possible sources of pollution to 
the river were revealed by PCA and they are categorized into natural and anthropogenic factors. Chemical weathering/lithologic dissolution, gold mining, fertilizer application and waste disposal are the major contributors whose signatures deteriorate the river quality. The presence of E.coli and total coliform in water is an indication of faecal contamination and the water should be boiled before consumption as these bacteria cannot withstand elevated temperature. Mining and farming activities in downstream of the river should not continue due to their negative impact on the river quality. Good sanitary habit should be adopted people living close to the river and the use of the river as toilet should and dumpsite should stop without any further delay. The effectiveness of MPI and PCA in river water quality studies has been demonstrated in this study.

\section{References}

Adams, R. H., Guzmán-Osorio, F. J., \& Zavala, C. J. (2008). Water repellency in oil contaminated sandy and clayey soils. International Journal of Environmental Science and Technology, 5(4), 445-454.

Ahmad, M. K., Islam, S., Rahman, S, Haque, M. R., \& Islam, M. M. (2010). Heavy metals in water, sediment and some fishes of Buriganga River, Bangladesh. International Journal of Environmental Resources, 4(2), 321-332.

Ajibade, A. C., \& Wright, J. B. (1988). Structural Relationship in the Schist Belts of North Western Nigeria. In P. O Oluyide et al. (Eds). Precambrian geology of Nigeria. A publication of Geological Survey, 103-109.

Akoto, O., Bruce, T. N., \& Darko, G. (2008). Heavy metals pollution profiles in streams serving the Owabi reservoir. African Journal of Environmental Science and Technology, 2(11), 354-359.

Aktar, M. W., Paramasivam. M., Ganguly, M., Purkait, S., \& Sengupta, D. (2010). Assessment and occurrence of various heavy metals in surface water of Ganga river around Kolkata: a study for toxicity and ecological $\begin{array}{llll}\text { impact. Environmental Monitoring and Assessment, 160(2), 207-213. } & \text {. }\end{array}$ http://dx.doi.org/10.1007/s10661-008-0688-5

Amadi, A. N. (2012). Quality Assessment of Aba River using heavy metal pollution index. American Journal of Environmental Enginerring, 2(1), 45-49.

Amadi, A. N., \& Olasehinde, P. I. (2010). Application of remote sensing techniques in hydrogeological mapping of parts of Bosso Area, Minna, North-Central Nigeria. International Journal of Physical Sciences, 5(9), $1465-1474$.

Amadi, A. N. (2011). Assessing the Effects of Aladimma dumpsite on soil and groundwater using water quality index and factor analysis. Australian Journal of Basic and Applied Sciences, 5(11), 763-770.

Amadi, A. N., Yisa, J., Okoye, N. O., \& Okunlola, I. A. (2010). Multivariate statistical evaluation of the hydrochemical facies in Aba, Southeastern Nigeria. International Journal of Biology and Physical Sciences, 15(3), 326-337.

Ammann, A. A., Michalke, B., \& Schramel, P. (2002). Speciation of heavy metals in environmental water by ion chromatography coupled to ICP-MS. Anal. Bioanal. Chemistry, 372(3), 448-452. http://dx.doi.org/10.1007/s00216-001-1115-8

APHA, (1998). Standard methods for examination of water and waste water (20th. Ed.). Washington DC: American Public Health Association.

Bellos, D., \& Swaidis, T. (2005). Chemical pollution monitoring of the River Pinios Thessalia-Greece. Journal of Environmental Management, 76, 282-292. http://dx.doi.org/10.1016/j.jenvman.2005.01.027

Bird, G., Brewer, P., Macklin, M., Balteanu, D., Driga, B., Serban, M., \& Zaharia, S., (2003). The solid state partitioning of contaminant metals and As in river channel sediments of the mining affected Tisa drainage basin, northwestern Romania and eastern Hungary. Applied Geochemistry, 18(10), 1583-1595. http://dx.doi.org/10.1016/S0883-2927(03)00078-7

Caerio, S., Costa, M. H., Ramos, T. B., Fernandes, F., Silveira, N., Coimbra, A., ... Painho, M. (2005). Assessing heavy metal contamination in Sado Estuary sediment: An index analysis approach. Ecological Indicators, 5, 155-169.

Cravotta, A. C. (2008). Dissolved metals and associated constituents in abandoned coal-mine discharges, Pennsylvania, USA. Part 1: Constituent quantities and correlations. Applied Geochemistry, 23(2), 166-202. http://dx.doi.org/10.1016/j.apgeochem.2007.10.011 
Filatov, N., Pozdnyakov, D., Johannessen, O., Pettersson, L., \& Bobylev, L. (2005). White Sea: Its Marine Environment and Ecosystem Dynamics Influenced by Global Change. UK: Springer and Praxis Publishing. pp. 1-472.

Gueu, S., Yao, B., Adouby, K., \& Ado, G. (2007). Kinetics and thermodynamics study of lead adsorption on to activated carbons from coconut and seed hull of the palm tree. International Journal of Environmental Sciences and Technology, 4(1), 11-17.

Hatje, V., Bidone, E. D., \& Maddock, J. L. (1998). Estimation of the natural and anthropogenic components of heavy metal fluxes in fresh water Sinos river, Rio Grande do Sul state, South Brazil. Environmental Technology, 19(5), 483-487. http://dx.doi.org/10.1080/095933331908616704

Juang, D. F., Lee, C. H., \& Hsueh, S. C. (2009). Chlorinated volatile organic compounds found near the water surface of heavily polluted rivers. International Journal of Environmental Science and Technology, 6(4), 545-556.

Kar, D., Sur, P., Mandal, S. K., Saha, T., \& Kole, R. K. (2008). Assessment of heavy metal pollution in surface water. International Journal of Environmental Science and Technology, 5(1), 119-124.

Karbassi, A. R., Monavari, S. M., Nabi-Bidhendi, G. R., Nouri, J., \& Nematpour, K. (2008). Metal pollution assessment of sediment and water in the Shur River. Environmental Monitoring and Assessment, 147(2), 107-116. http://dx.doi.org/10.1007/s10661-007-0102-8

Karbassi, A. R., Nouri, J., \& Ayaz, G. O. (2007). Flocculation of trace metals during mixing of Talar river water with Caspian Seawater. International Journal of Environmental Resources, 1(1), 66-73.

Khadse, G. K., Patni, P. M., Kelkar, P. S., \& Devotta, S. (2008). Qualitative evaluation of Kanhan river and its tributaries flowing over central Indian plateau. Environmental Monitoring and Assessment, 147(1-3), 83-92. http://dx.doi.org/10.1007/s10661-007-0100-x

Kraft, C., Tumpling, W., \& Zachmann, D. W. (2006). The effects of mining in Northern Romania on the heavy metal distribution in sediments of the rivers Szamos and Tisza (Hungary). Acta Hidrochim, Hyhydrobiology, $34,257-264$.

Lambarkis, N., Antonakos, A., \& Panagopoulos, G. (2004). The use of multi-component statistical analysis in hydrogeological environmental research. Water Resources, 38(7), 1862-1872.

Lee, C. L., Li, X. D., Zhang, G., Li, J., Ding, A. J., \& Wang, T. (2007). Heavy metals and Pb isotopic composition of aerosols in urban and suburban areas of Hong Kong and Guangzhou, South China Evidence of the long-range transport of air contaminants. Environmental Pollution, 41(1), 432-447.

Lohani, M. B., Singh, S., Rupainwar, D. C., \& Dhar, D. N. (2008). Seasonal variations of heavy metal contamination in river Gomti of Lucknow city region. Environmental Monitoring and Assessment, 147(3), 253-263. http://dx.doi.org/10.1007/s10661-007-0117-1

Lyulko, I., Ambalova, T., \& Vasiljeva, T. (2001). To Integrated Water Quality Assessment in Latvia. MTM (Monitoring Tailor-Made) III, Proceedings of International Workshop on Information for Sustainable Water Management. Netherlands, 449-452.

Macklin, M. G., Brewer, P. A., Balteanu, D., Coulthard, T. J., Driga, B., Howard, A. J., \& Zaharia, S. (2003). The long term fate and environmental significance of contaminant metals released by the January and March 2000 mining tailings dam failure in Maramures County, upper Tisa basin, Romania. Applied Geochemistry, 18(2), 241-257. http://dx.doi.org/10.1016/S0883-2927(02)00123-3

Mohan, S. V., Nithila, P., \& Reddy, S. J. (1996). Estimation of heavy metal in drinking water and development of heavy metal pollution index. Journal of Environmental Science and Health, 31(3), 283-289. http://dx.doi.org/10.1080/10934529609376357

Mohanty, J. K. Misra, S. K., \& Nayak, B. B. (2001). Sequential leaching of trace elements in coal: A case study from Talcher coalfield, Orissa. Journal of Geology and Sociology India, 58, 441-447.

NGSA, (2004). Modified Geological map of parts of Minna, Niger State, from Nigerian Geological Survey Agency, 24-30.

Nikolaidis, C., Mandalos, P., \& Vantarakis, A. (2008). Impact of intensive agricultural practices on drinking water quality in the EVROS Region (NE GREECE) by GIS analysis. Environmental Monitoring and Assessment, 143(3), 43-50. http://dx.doi.org/10.1007/s10661-007-9955-0 
Nouri, J., Mahvi, A. H., Babaei, A., \& Ahmadpour, E. (2006). Regional pattern distribution of groundwater fluoride in the Shush aquifer of Khuzestan County Iran Fluoride. Fluoride, 39(4), 321-325.

Nouri, J., Mahvi, A. H., Jahed, G. R., \& Babaei, A. A. (2008). Regional distribution pattern of groundwater heavy metals resulting from agricultural activities. Environmental Geology, 55(6), 1337-1343. http://dx.doi.org/10.1007/s00254-007-1081-3

NSDWQ. (2007). Nigerian Standard for Drinking Water Quality. Nigerian Industrial Standard, NIS: 554, pp. 13-14.

Prasad, B., \& Kumari, S. (2008). Heavy metal pollution index of ground water of an abandoned open cast mine filled of the water quality of River Adyar, India. Bulletin of Environmental Contamination and Toxicology, 82(2), 211-217.

Prasad, B., \& Mondal, K. K. (2008). The impact of filling an abandoned opencast mine with fly ash on ground water quality: A case study. Mine, Water and Environment, 27(1), 40-45. http://dx.doi.org/10.1007/s10230-007-0021-5

Rim-Rukeh, A., Ikhifa, O. G., \& Okokoyo, A. P. (2006). Effects of agricultural activities on the water quality of Orogodo River, Agbor Nigeria. Journal of Applied Sciences and Reserch, 2(5), 256-259.

Sekabira, K., Oryem-Origa, H., Basamba, T. A., Mutumba, G., \& Kakudidi, E. (2010). Assessment of heavy metal pollution in the urban stream sediments and its tributaries. International Journal of Environmental Science and Technology, 7(3), 435-446.

Shahtaheri, S. J., Abdollahi, M., Golbabaei, F., Rahimi-Froushani, A., \& Ghamari, F. (2008). Monitoring of mandelic acid as a biomarker of environmental and occupational exposures to styrene. International Journal of Environmental Resources, 2(2), 169-176.

Singh, A. K., Mondal, G. C., Kumar S., Singh, T. B., Tewary, B. K., \& Sinha, A. (2008). Major ion chemistry, weathering processes and water quality assessment in upper catchment of Damodar River basin. Indian Environ. Geo., 54(4), 745-758. http://dx.doi.org/10.1007/s00254-007-0860-1

Singh, K. P., Mallik, A., Mohan, D., \& Sinha, S. (2004). Multivariate statistical techniques for the evalution of spatial and temporal variations in water quality of Gomti River (India): A case study. Water Resources, 38(18), 3980-3992.

Sundaray, S. K. (2009). Application of multivariate statistical techniques in hydro-geochemical studies-a case study: Brahmani-Koel River (India). Environmental Monitoring and Assessment, 164(4), 297-310. http://dx.doi.org/10.1007/s10661-009-0893-x

Sundaray, S. K., Panda, U. C., Nayak, B. B., \& Bhatta, D. (2006). Multivariate statistical techniques for the evaluation of spatial and temporal variation in water quality of Mahanadi river-estuarine system (India), A case study. Environmental Geochemistry and Health, 28(4), 317-330. http://dx.doi.org/10.1007/s10653-005-9001-5

Suthar, S., \& Singh, S. (2008). Vermicomposting of domestic waste by using two epigeic earthworms (Perionyx excavates and Perionyx sansibaricus). International Journal of Environmental Science and Technology, 5(1), 99-106.

Tamasi, G., \& Cini, R. (2004). Heavy metals in drinking waters from Mount Amiata. Possible risks from arsenic for public health in the province of Siena. Science of the Total Environment, 327, 41-51. http://dx.doi.org/10.1016/j.scitotenv.2003.10.011

USEPA. (1997). National Hardrock Mining Framework. EPA, 833-B-97-003.

Venugopal, T., Giridharan, L., \& Jayaprakash, M. (2009). Characterization and risk assessment studies of bed sediments of River Adyar-An application of speciation study. International Journal of Environmental Resources, 3(4), 581-598.

Vinodhini, R., \& Narayanan, M. (2008). Bioaccumulation of heavy metals in organs of fresh water fish Cyprinus carpio (Common carp). International Journal of Environmental Science and Technology, 5(2), 179-182. 